\author{
ACTA MYCOLOGICA \\ Vol. 43 (2): 153-159 \\ 2008
}

\title{
New records of smut fungi from Venezuela: Anthracoidea uleana, Sporisorium panici-petrosi and Ustilago schroeteriana
}

\author{
MARCIN PIĄTEK \\ Department of Mycology, W. Szafer Institute of Botany, Polish Academy of Sciences \\ Lubicz 46, PL-31-512 Kraków, mpiatek@ib-pan.krakow.pl
}

Piątek M.: New records of smut fungi from Venezuela: Anthracoidea uleana, Sporisorium panicipetrosi and Ustilago schroeteriana. Acta Mycol. 43 (2): 153-159, 2008.

Three smut fungi from Venezuela are described, illustrated and discussed based on newly studied collections. Ustilago schroeteriana Henn. is reported for the first time from the country. Anthracoidea uleana (Syd. \& P. Syd.) Vánky is confirmed in Venezuela on Carex longii Mack., which is an accessory host for this smut. Sporisorium panici-petrosi (Syd. \& P. Syd.) M. Piepenbr. is reported on Thrasya sp. from a second world locality in northern Venezuela, its description is slightly expanded and issues concerning typification of this name and the nomenclature of the host in the type collection are clarified and corrected.

Key words: Anthracoidea, Ustilago, Sporisorium, smut fungi, Neotropics, South America

\section{INTRODUCTION}

Neotropical smut fungi have been recently monographed by Piepenbring (2003) who listed 227 species from this part of North and South America. This number seems to be not final, and the author considers that many new species can be discovered in the area as well as numerous species can be found in particular countries as a new national records. Indeed several further new species have been subsequently described from different parts of Neotropics (Vánky 2004, 2005, 2006).

Venezuela is the sixth largest country of South America, located at the northern coast of the continent, bordering with Colombia, Brazil, Guyana and the Caribbean Sea. The country has very diverse, tropical landscape, vegetation and vascular plant flora. As in most of neotropical countries, the of smut fungi of Venezuela are insufficiently known, and altogether 57 species have been reported from the country till now (Sydow and Sydow 1916; Jackson 1934; Dennis 1970; Nannfeldt 1977; Piepenbring 2003; Vánky 2005, 2006, 2007). During ongoing studies focusing on biodiversity of tropical smut fungi, I examined three unidentified collections from Venezuela. They belonged to three species, Anthracoidea uleana (Syd. \& P. Syd.) Vánky, Sporisorium panici-petrosi (Syd. \& P. Syd.) M. Piepenbr. and Ustilago schroeteriana Henn. Of these, Ustilago schroeteriana is new to Venezuela, while two remaining 
species are reported for the second time from the country. These new collections are described, illustrated and discussed in the present contribution.

\section{MATERIALS AND METHODS}

Dried herbarium specimens were examined by light microscopy (LM) and scanning electron microscopy (SEM). For LM, small pieces of sori were mounted in heated lactophenol and examined under a NIKON Eclipse E600 light microscope. For SEM, spores were dusted onto carbon tabs and fixed to an aluminium stub with double-sided transparent tape. The stubs were sputter-coated with carbon using a CRESSINGTON sputter-coater and viewed with a Hitachi S-4700 scanning electron microscope, with a working distance of ca $12-13 \mathrm{~mm}$. SEM micrographs were taken in the Laboratory of Field Emission Scanning Electron Microscopy and Microanalysis at the Institute of Geological Sciences, Jagiellonian University, Kraków (Poland).

\section{RESULTS AND DISCUSSION}

Anthracoidea uleana (Syd. \& P. Syd.) Vánky (as “uleiana"), Mycotaxon 62: 144 (1997) (Fig. 1.)

BASIONYM: Cintractia uleana Syd. \& P. Syd., Ann. Mycol. 14: 73 (1916)

TyPE: On Carex cf. bonplandii Kunth (as Carex sp.), Brazil, Roraima, Dec. 1909, leg. E. Ule 3376 (LECTOTYPE: BPI 172260, designated by Vánky 1997: 144, ISOTYPE: BPI 172261).

For further synonyms see Piepenbring (2003: 46).

Sori in ovaries, as black, globose, hard bodies around the ovaries, about 1-1.5 $\mathrm{mm}$ in diameter, partly hidden by the scales, composed of agglutinated spores, powdery on the surface. - Spores very variable in shape, rounded, bluntly polyhedral, 12-19 $\times 10-17 \mu \mathrm{m}$, olive-brown to dark brown, with 3-5 light, thin-walled, rounded areas that are collapsed and often form characteristic mamillate depressions, which are especially well visible on the SEM micrographs; wall uneven, 1-3 $\mu \mathrm{m}$ thick, thickest at the angles, internal swellings and light refractive spots absent, surface as seen by LM finely punctate to verruculose, warts not affecting the spore profile, surface as seen by SEM finely verruculose.

Specimens examined: On Carex longii Mack. (det. M. Piątek), Venezuela, State Mérida, La Carbonera, Finca San Isidro, alt. ca. 2400 m, moist pasture, 12 Jan. 1979, leg. T. Ahti 37336, M. López Figuieras \& P. M. Jørgensen (H); Venezuela, State of Lara, W of Humocaro Bajo, at Las Sabanetas above Los Aposentos, alt. ca. $2530 \mathrm{~m}$, wet meadow, 5 Feb. 1944, leg. J. A. Steyermark (H.U.V. 7638 ex NY ex H).

Anthracoidea uleana is easy to identify because of unusual spores, which are quite small and possess 3-5 light, thin-walled, rounded areas. These areas are collapsed and often form mamillate depressions, which are especially well visible on the SEM micrographs. The host plants of $A$. uleana belong to Carex subgen. Vigna sect. Ovales. The only other neotropical Anthracoidea Bref. with similar appearance of spores is Anthracoidea altiphila Vánky \& M. Piepenbr., which however differs by some small morphological characters and host plants belonging to Carex subgen. Carex sect. Fecundae (Vánky 1994).

Anthracoidea uleana is one of the four species of Anthracoidea known from the Neotropics (Piepenbring 2003). The small number of species in this floral kingdom 

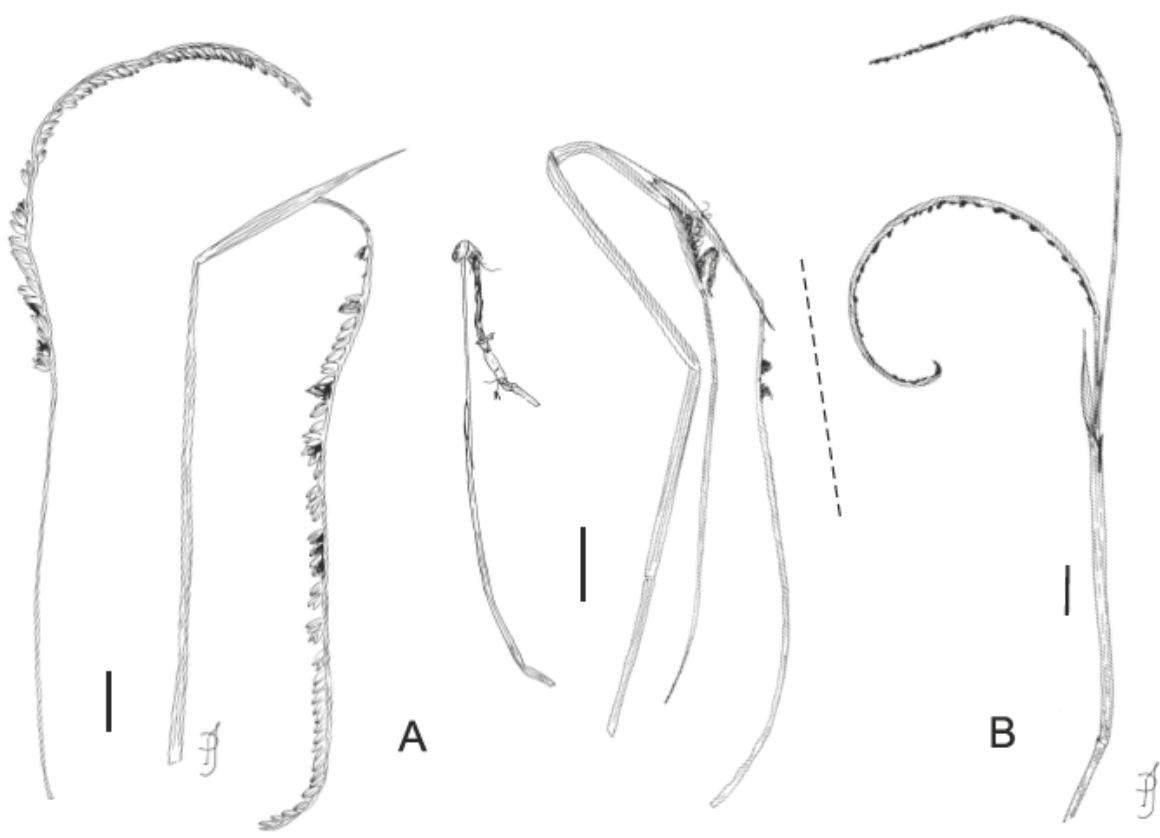

Fig. 4. - A. Sporisorium panici-petrosi (Syd. \& P. Syd.) M. Piepenbr. on Thrasya sp. [all from K(M) 134340]: to the left two plants with sori restricted to individual spikelets, to the right two plants with sori replacing the whole inflorescences. - B. Ustilago schroeteriana Henn. on Thrasya sp. [from K(M) 134340]: sori destroying all spikeletes and peripheral axial tissues of an inflorescences. - Scale bars $=1 \mathrm{~cm}$.

is not unusual since the genus is predominantly known from temperate, boreal and arctic zones of the world, with the main centre of diversity in the Holarctic kingdom. In the Neotropics, Anthracoidea is restricted to high altitudes, as also A. uleana does. The species is exclusively neotropical and known from numerous stations located in swamps at elevations of ca 2400-3900 m a.s.l. in Costa Rica, Colombia, Ecuador, Panama, Peru, Brazil and Bolivia (Piepenbring 2003, 2006). The majority of known localities is in Colombia and Costa Rica and single locations are known in the remaining countries (Fig. 5). All these reports are on Carex bonplandii Kunth.

In his monograph of Anthracoidea infecting Carex subgen. Vignea, Nannfeldt (1977) wrote that Illka Kukkonen informed him that he has seen a sample of this peculiar smut on "Carex longii Mack." from Venezuela. However, neither Nannfeldt nor Kukkonen provided any characterization of this collection. In fact, I have seen part of it in a private herbarium of K. Vánky (H.U.V.), but did not examine it in detail. The present collection is the second record of Anthracoidea uleana on Carex longii. Except for somewhat larger spores and thicker spore wall, the specimen corresponds well to specimens on Carex bonplandii. This finding confirms the presence of $A$. uleana in Venezuela and Carex longii as a host plant of this smut. Thus, C. bonplandii is a principal host, while $C$. longii must be treated as an accessory host of Anthracoidea uleana. 
Sporisorium panici-petrosi (Syd. \& P. Syd.) M. Piepenbr., Flora Neotropica 86: 122 (2003) (Figs 2 and 4A)

BASIONYM: Ustilago panici-petrosi Syd. \& P. Syd., Ann. Mycol. 14: 73 (1916)

TyPE: On Thrasya petrosa (Trin.) Chase (=Panicum petrosum Trin.), Venezuela, Amazonas, Kata, Rio Cuquenan, Dec. 1909, leg. E. Ule 3331 (LeCTOTYPE: S, designated by Vánky 2005: 243, erroneously as neotype, ICBN Art. 9.8).

Sori usually replacing the whole inflorescence, long, elongated, up to $5 \mathrm{~mm}$ wide and up to $10 \mathrm{~mm}$ long, sometimes partly concealed by leaf sheaths, at first covered by thick, pale brown peridium, which ruptures irregularly exposing dark brown powdery mass of spores surrounding numerous filiform columellae that are sometimes connected with each other. Sori rarely restricted to spikelets, replacing flowers with dusty mass of spores, enclosed by a pale brown peridium and surrounding filiform columellae, partly concealed by glumes. - Spores yellowish-brown, on one side lighter coloured, pale yellowish or almost hyaline, globose, subglobose to slightly irregular, 9-13(-15) $\times(7-) 8.5-12 \mu \mathrm{m}$; wall ca. $0.5 \mu \mathrm{m}$ thick, thinner on the lighter coloured side, surface as seen by LM finely verruculose, spore profile smooth, surface as seen by SEM moderately verruculose. - Sterile cells absent.

Specimen EXAmined: On Thrasya sp., Venezuela, Estado Miranda, Caracas, above Los Palos Grandes, S slope of Monte Naiguata, 1200 m a.s.l., 24 Aug. 1958, leg. R.W.G. Dennis 2364 [K(M) 134340, together with Ustilago schroeteriana].

Sporisorium panici-petrosi was so far known only from the type locality in southern Venezuela. The collection from northern Venezuela reported here represents

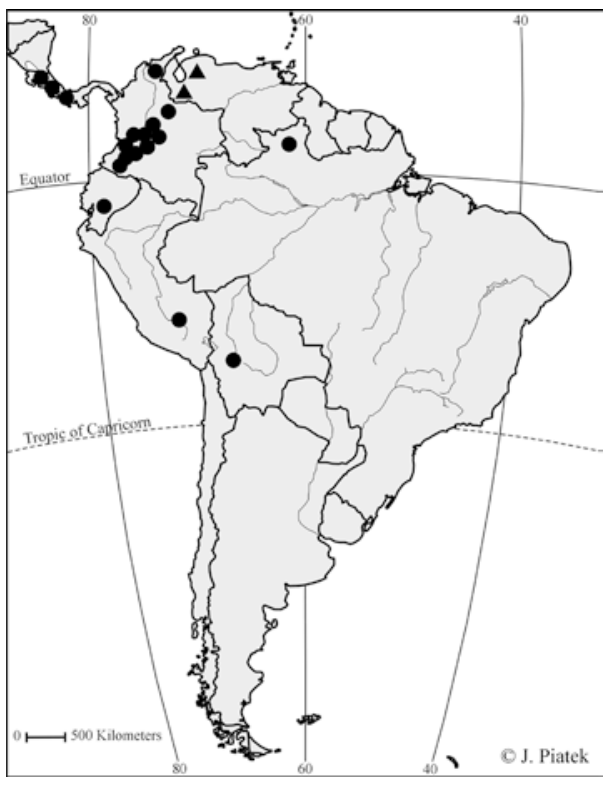

Fig. 5. Global distribution of Anthracoidea uleana (Syd. \& P. Syd.) Vánky with records on Carex bonplandii Kunth marked by black dots and records on Carex longii Mack. marked by triangles (modified from Piepenbring 2003). the second record of this smut (Fig. 6). The presence of unusual columellae that are connected with each other as well as characteristic spores that are lighter coloured on one side makes this species easy to identify. According to the descriptions (Piepenbring 2003; Vánky 2005) of the type collection, the smut destroys whole inflorescences; in the new collection from northern Venezuela, however, the sori are restricted only to individual spikelets in some plants while they destroy whole inflorescences in others.

The smut was originally described in the genus Ustilago (Pers.) Roussel as U. panici-petrosi Syd. \& P. Syd., but because of the presence of the peridium and columellae, Piepenbring (2003) transferred it to Sporisorium Ehrenb. ex Link. Vánky (2005) did not accept this proposal, since in his opinion the manner of spore formation in this species is rather of the Ustilago-type, and the spores with a thinner wall on one side are typical 
of numerous species of Ustilago. However, sporogenesis was analysed in detail only in some species of Sporisorium and Ustilago (e.g., Langdon and Fullerton 1975, 1978), and it is not clear whether the way of spore formation is a constant character of taxonomic importance. This is particularly essential in light of recent molecular analyses (Stoll et al. 2005) in which Sporisorium appeared to be a polyphyletic genus. Therefore, the taxonomic value of spore formation in delimiting the genera Ustilago and Sporisorium should be checked by careful studies of ontogeny and sporogenesis in numerous species, preferably based on freshly collected specimens. In contrast to the statement of Vánky (2005), the spores with a thinner wall on one side are known not only in the genus Ustilago, but also in several species of Sporisorium, for instance in $S$. clandestinum R.G. Shivas, Vánky \& P. Athipunyakom (Vánky et al. 2006), S. sphacelatum Vánky (Vánky 2003), S. wynaadense (Sundaram) Vánky

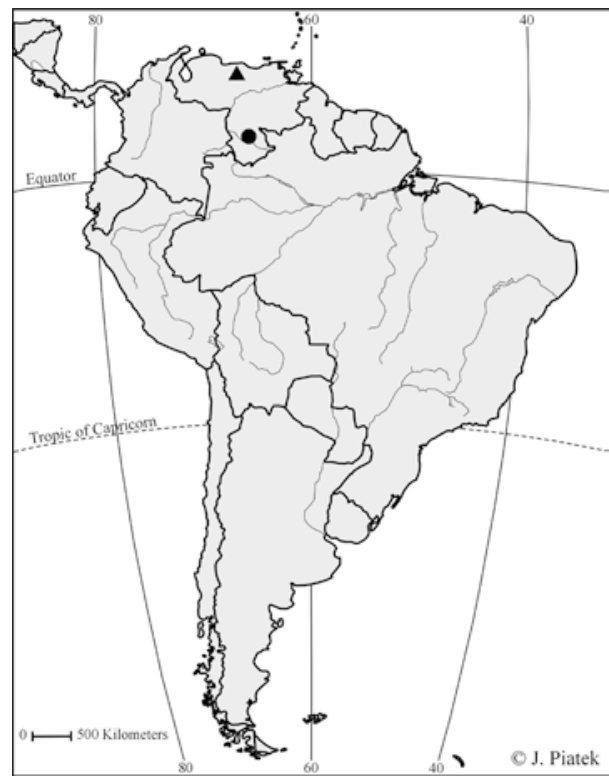

Fig. 6. Global distribution of Sporisorium panici-petrosi (Syd. \& P. Syd.) M. Piepenbr. with new locality in northern Venezuela marked by triangle (modified from Piepenbring 2003). \& R.G. Shivas (Vánky and Shivas 2001). Therefore, this character is not useful in delimiting the genera Ustilago and Sporisorium. In conclusion, I follow the proposal of Piepenbring (2003), who placed Ustilago panici-petrosi in Sporisorium, also because the general appearance of this smut is similar to the species included in this genus.

The host plant of Sporisorium panici-petrosi was originally named Panicum petrosum Trin., and for that reason this smut was analysed in the monograph of smut fungi infecting Panicum species (Vánky 2005). However, Panicum petrosum is currently placed in the genus Thrasya, as T. petrosa (Trin.) Chase, which is phylogenetically more closely related to Paspalum than to Panicum (Giussani et al. 2001). The new collection from northern Venezuela reported here is on unidentified species of Thrasya. In addition, in the same collection there are some plants infected by Ustilago schroeteriana, which is a typical Paspalum smut. Therefore, Sporisorium panicipetrosi must be excluded from Panicum smuts.

The holotype of Ustilago panici-petrosi was destroyed in 1943 by Berlin fire along with a greater part of the Berlin herbarium. Fortunately, a duplicate of this collection is preserved in Stockholm (herb. S). Piepenbring (2003) considered the latter specimen as holotype, which is, however, incorrect as the main collection of the Sydows was housed in Berlin. Vánky (2005) designated the specimen preserved in Stockholm (herb. S) as neotype. That denoting is also incorrect, because a neotype can be selected only when all the original material is lost, which is not the case here. Therefore, Vánky's denoting is treated as an error (Art. 9.8 of ICBN), and the specimen in herb. S must be treated as the lectotype of Ustilago panici-petrosi. 
Ustilago schroeteriana Henn., Hedwigia 35: 215 (1896) (Figs 3 and 4B)

TYPE: On Paspalum sp., Brazil, St. Catharina, near Itajahy, Nov. 1885, leg. E. Ule 1615 (ноцоTYPE: HBG, ISOTYPES: NHES, BPI 166243, 166244, 166245, 194460, H.U.V. 16460).

For further synonyms and types see Piepenbring (2003: 184) and Vánky (2007: 5).

Sori destroying all spikeletes and peripheral axial tissues of an inflorescence, retaining the shape of affected organs, with shredded remnants of host plant tissue attached to them, spore mass dark brown, powdery. - Spores yellow-brown, globose, subglobose to ovoid, variable in size, 13-17(-19) × 12-16(-17) $\mu \mathrm{m}$; wall even, ca. 1-1.5 $\mu \mathrm{m}$ thick, surface as seen by LM finely verruculose, spore profile finely wavy, surface as seen by SEM moderately densely verruculose with punctate warts in the interspaces.

SPecimen eXAmined: On Thrasya sp., Venezuela, Estado Miranda, Caracas, above Los Palos Grandes, S slope of Monte Naiguata, $1200 \mathrm{~m}$ a.s.l., 24 Aug.

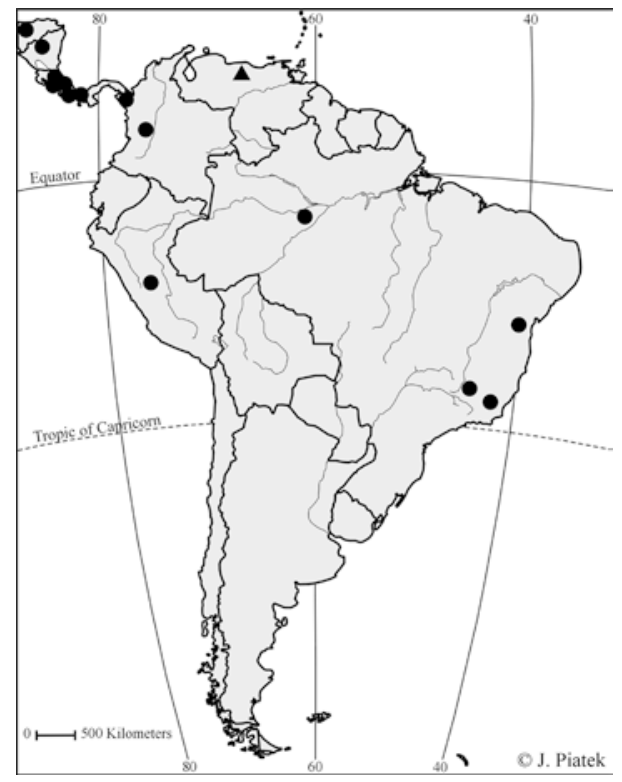

Fig. 7. Distribution of Ustilago schroeteriana Henn. in South America (black dots) with new locality in northern Venezuela marked by triangle (modified from Piepenbring 2003). 1958, leg. R.W.G. Dennis 2364 [K(M) 134340, together with Sporisorium panici-petrosi].

The morphology of sori and spores of the present collection matches well with those given in descriptions of Ustilago schroeteriana (Piepenbring 2003; Vánky 2007), but the spore sizes are closer to these given by Piepenbring (2003): (13-)14-17(-20) $\times(11-) 12-15(-17) \mu \mathrm{m}$, than by Vánky (2007): 13.5-20 × 12-18.5 $\mu \mathrm{m}$. The former author pointed out that the spore sizes in different collections of $U$. schroeteriana are fairly variable, but the most measurements are about 15-17 $\mu \mathrm{m}$. Vánky (2007) in his description gives only extreme values and does not specify which measurements are most common.

Ustilago schroeteriana is widespread in the Neotropics on different species of Paspalum, being known from Belize, Brazil, Colombia, Costa Rica, Cuba, Granada, Honduras, Mexico, Nicaragua, Panama, Peru and Puerto Rico (Piepenbring 2003; Pérez and Minter 2005). The present record is new to Venezuela (Fig. 7) on the new host plant genus Thrasya. The molecular phylogenetic studies (Giussani et al. 2001) showed that Thrasya is closely related to Paspalum and the presence of the same smut fungus on these two host genera additionally supports this close relationship.

Acknowledgements. I am grateful to my wife Jolanta Piątek (Kraków, Poland) for her drawings, to Anna Łatkiewicz (Kraków, Poland) for help with the SEM pictures, and to the Curators of $\mathrm{H}$ and $\mathrm{K}$ for the loan of specimens. This work was partly supported by the Polish Ministry of Science and Higher Education (grant no. 2 P04G 01928 for the years 2005-2008). 


\section{REFERENCES}

Dennis R. W. G. 1970. Fungus flora of Venezuela and adjacent countries. Kew Bull. Add. Ser. 3: 1-531.

Giussani L. M., Cota-Sánchez J. H., Zuloaga F. O., Kellogg E. A. 2001. A molecular phylogeny of the grass subfamily Panicoideae (Poaceae) shows multiple origins of $\mathrm{C}_{4}$ photosynthesis. Amer. J. Bot. 88 (11): 1993-2012.

Jackson H. S. 1934. Ustilaginales. (In:) C. E. Chardon, R. A. Toro (eds), Mycological explorations of Venezuela. Univ. Puerto Rico Monogr. Ser. B., 2: 256-261.

Langdon R. F. N., Fullerton R. A. 1975. Sorus ontogeny and sporogenesis in some smut fungi. Austral. J. Bot. 23: 915-930.

Langdon R. F. N., Fullerton R. A. 1978. The genus Sphacelotheca (Ustilaginales): Criteria for its delimitation and the consequences thereof. Mycotaxon 6: 421-456.

Nannfeldt J. A. 1977. The species of Anthracoidea (Ustilaginales) on Carex subgen. Vignea with special regard to the Nordic species. Bot. Notiser 130: 351-375.

Pérez J. M., Minter D. W. 2005. Ustilago schroeteriana. [Descriptions of Fungi and Bacteria]. IMI Descriptions of Fungi and Bacteria, No. 164, Sheet 1640.

Piepenbring M. 2003. Smut fungi (Ustilaginomycetes p.p. and Microbotryales, Basidiomycota). Flora Neotropica 86: iv+1-291.

Piepenbring M. 2006. Neue Ergebnisse zur Diversität und Ökologie von Brandpilzen in Panama. Z. Mykol. 72(2): 89-100.

Stoll M., Begerow D., Oberwinkler F. 2005. Molecular phylogeny of Ustilago, Sporisorium, and related taxa based on combined analyses of rDNA sequences. Mycol. Res. 109: 342-356.

Sydow H., Sydow P. 1916. Fungi amazonici a cl. E. Ule lecti. Ann. Mycol. 14: 65-97.

Vánky K. 1994. Taxonomical studies on Ustilaginales. XI. Mycotaxon 51: 153-174.

Vánky K. 1997. Taxonomical studies on Ustilaginales. XV. Mycotaxon 62: 127-150.

Vánky K. 2003. Taxonomical studies on Ustilaginales. XXIII. Mycotaxon 85: 1-65.

Vánky K. 2004. New smut fungi (Ustilaginomycetes) from Mexico, and the genus Lundquistia. Fungal Divers. 17: 159-190.

Vánky K. 2005. Taxonomic studies on Ustilaginomycetes - 25. Mycotaxon 91: 217-272.

Vánky K. 2006. Taxonomic studies on Ustilaginomycetes - 26. Mycotaxon 95: 1-65.

Vánky K. 2007. Taxonomic studies on Ustilaginomycetes - 27. Mycotaxon 99: 1-70.

Vánky K., Shivas R. G. 2001. Smut fungi (Ustilaginomycetes) of Sorghum (Gramineae) with special regard to Australasia. Mycotaxon 80: 339-353.

Vánky K., Shivas R. G., Athipunyakom P. 2006. New smut fungi (Ustilaginomycetes) from Thailand. Mycol. Balcanica 3(2-3): 107-118.

\section{Nowe stwierdzenia grzybów głowniowych w Wenezueli: Anthracoidea uleana, Sporisorium panici-petrosi i Ustilago schroeteriana}

\section{Streszczenie}

W pracy zaprezentowano trzy gatunki grzybów głowniowych z Wenezueli, stwierdzone podczas rutynowego oznaczania niezidentyfikowanych materiałów pochodzących z obszarów tropikalnych. Ustilago schroeteriana Henn. jest nowy dla tego kraju. Anthracoidea uleana (Syd. \& P. Syd.) Vánky jest podany z drugiego stanowiska w Wenezueli. Sporisorium panici-petrosi (Syd. \& P. Syd.) M. Piepenbr. jest podany z drugiego stanowiska na świecie w północnej Wenezueli. W pracy rozszerzono nieco opis tego gatunku o nowe cechy diagnostyczne i wyjaśniono lub poprawiono niektóre błędne informacje dotyczące jego typizacji i nomenklatury rośliny żywicielskiej. 

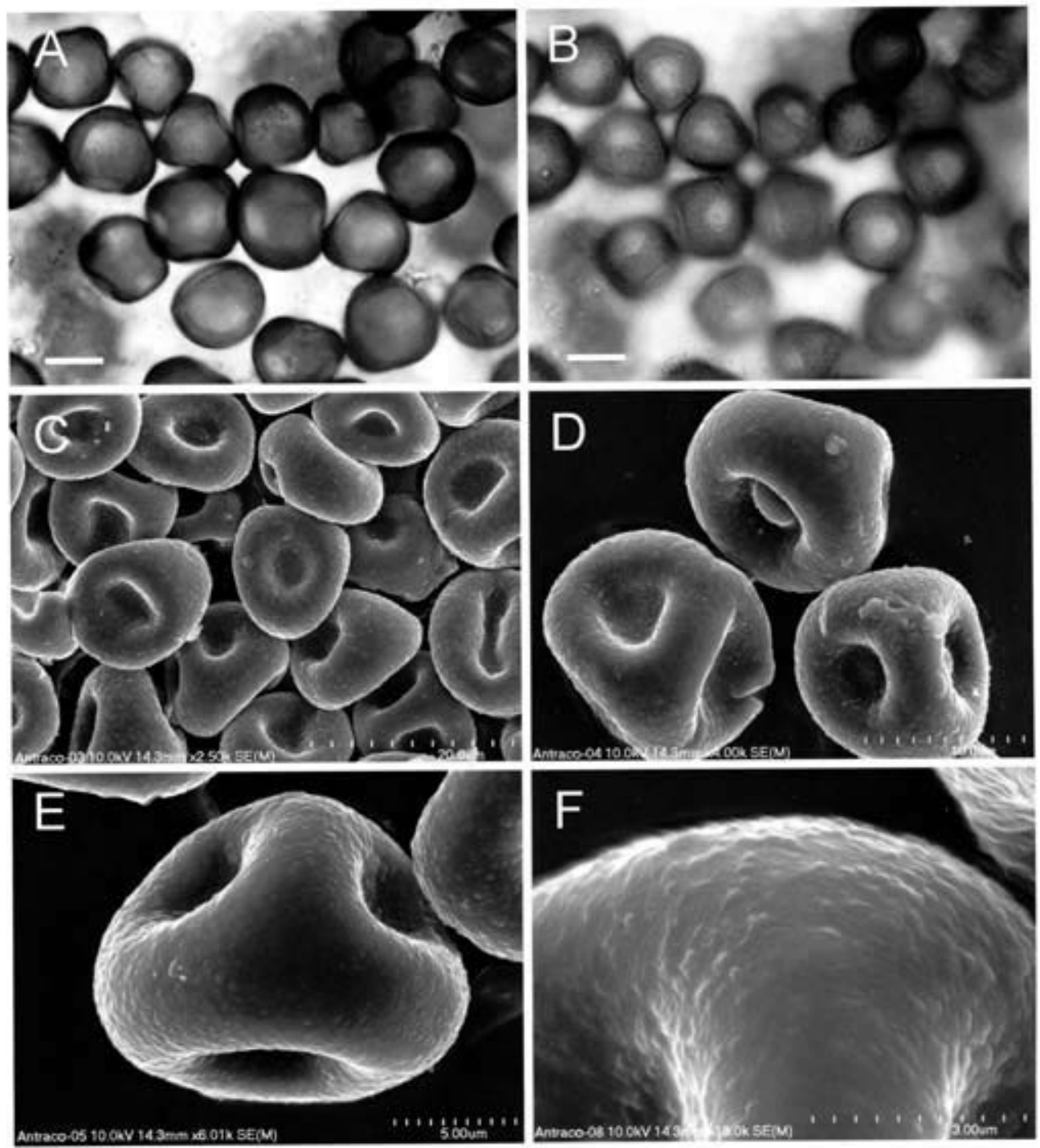

Fig. 1. Anthracoidea uleana (Syd. \& P. Syd.) Vánky on Carex longï Mack. (all from H): A. Spores seen by LM, median view. - B. Spores seen by LM, surface view, - C-E. Spores seen by SEM. - F. Spore wall seen by SEM. - Scale bars $=3 \mu \mathrm{m}$ (Fig. F), $5 \mu \mathrm{m}$ (Fig. E), $10 \mu \mathrm{m}$ (Figs A-B and D), $20 \mu \mathrm{m}$ (Fig. C). 

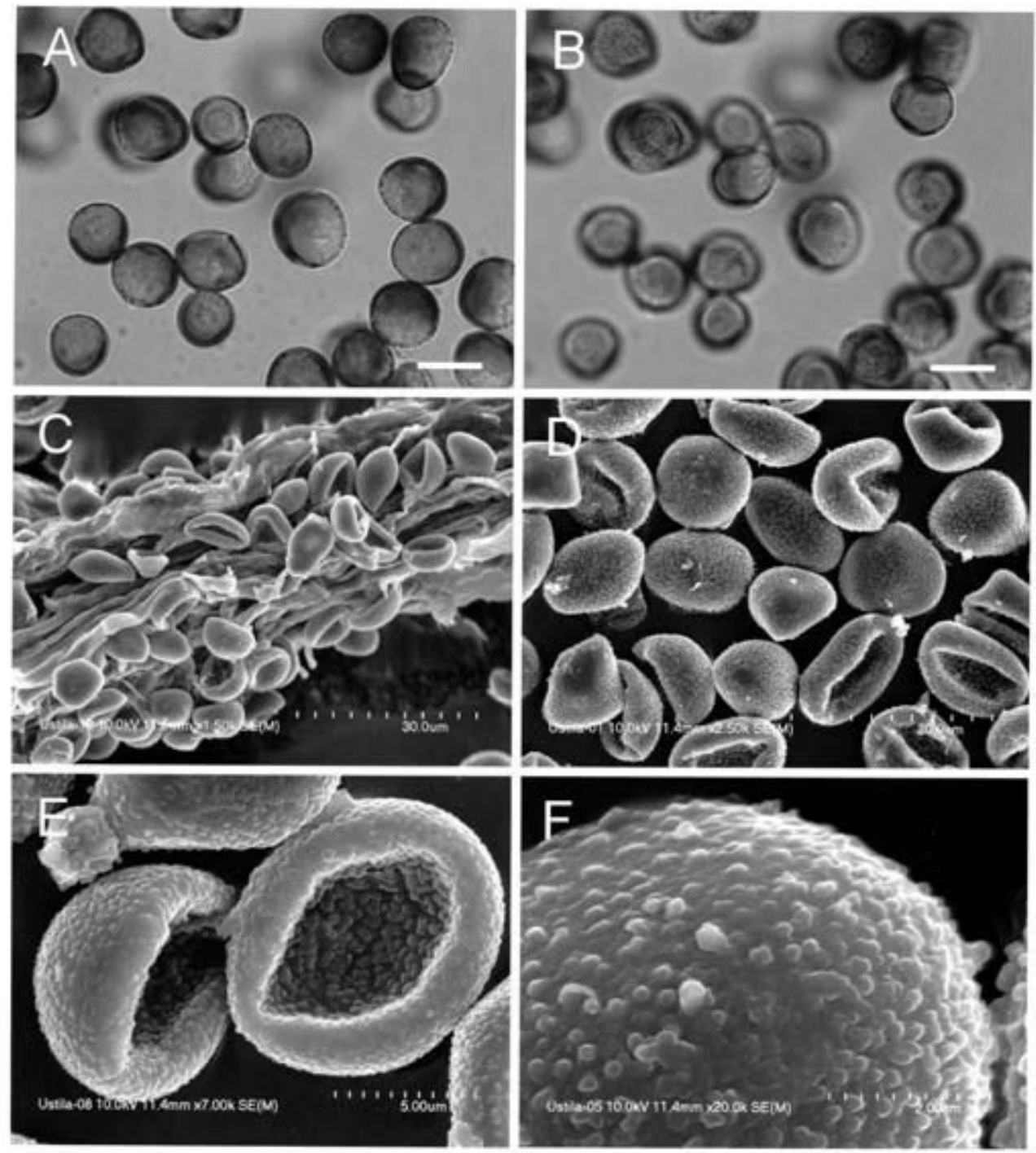

Fig. 2. Sporisorium panici-petrosi (Syd. \& P. Syd.) M. Piepenbr, on Thrasya sp. [all from K(M) 134340]: A. Spores seen by LM, median view, - B. Spores seen by LM, surface view. C. Spores and fragment of columella seen by SEM. - D-E. Spores seen by SEM. - F. Spore wall seen by SEM. - Scale bars $=2 \mu \mathrm{m}$ (Fig, F), $5 \mu \mathrm{m}$ (Fig. E), $10 \mu \mathrm{m}$ (Figs A-B), $20 \mu \mathrm{m}$ (Fig. D), $30 \mu \mathrm{m}$ (Fig. C). 

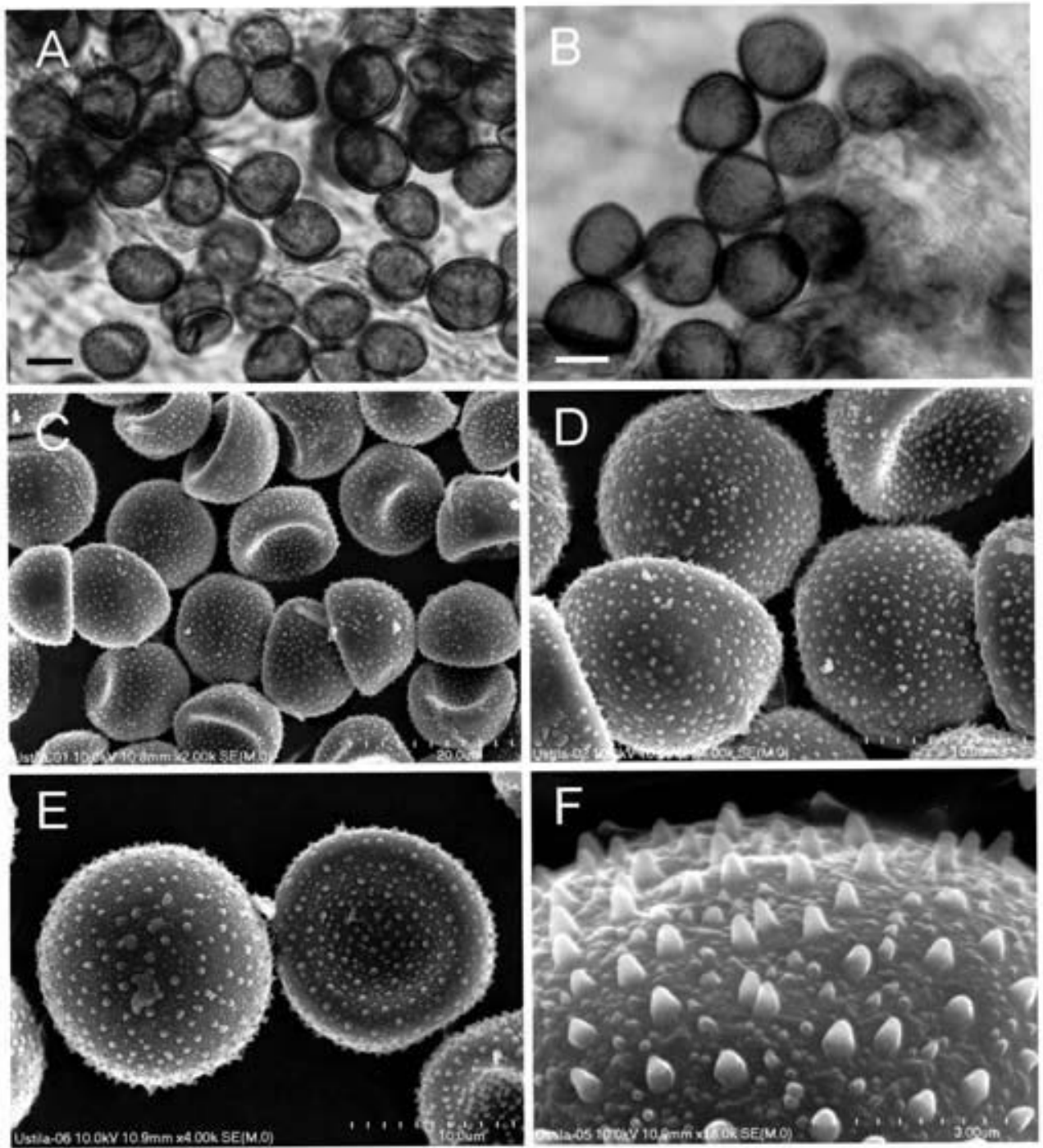

Fig. 3. Ustilago schroeteriana Henn. on Thrasya sp. [all from K(M) 134340]: A. Spores in LM, median view. - B. Spores in LM, surface view. - C-E. Spores seen by SEM. - F. Spore wall seen by SEM. - Scale bars $=3 \mu \mathrm{m}$ (Fig. F), $10 \mu \mathrm{m}$ (Figs A-B and D-E), $20 \mu \mathrm{m}$ (Fig. C). 